\title{
On-the-Job Training Program Evaluation of Business Administration and Accountancy Departments of University of Saint Louis
}

\author{
Karen Joy A. Catacutan ${ }^{1, *}$, Alicia S. Tuliao ${ }^{2}$ \\ ${ }^{1}$ Center for Business Research and Development, University of Saint Louis, Philippines \\ ${ }^{2}$ School of Accountancy, Business and Hospitality, University of Saint Louis, Philippines
}

Received October 24, 2019; Revised November 16, 2019; Accepted November 19, 2019

Copyright $\mathrm{C} 2020$ by authors, all rights reserved. Authors agree that this article remains permanently open access under the terms of the Creative Commons Attribution License 4.0 International License

\begin{abstract}
This study was conducted to assess the implementation of the on-the-job training program Business Administration and Accountancy Departments of the University of Saint Louis, one of the Higher Education Institutions in the Northern Philippines. The study utilized a descriptive method of research and a total of 142 undergraduate students who had their on-the-job training among government and private financial and non-financial institutions responded in the school year 2018-2019 were the respondents of the study and this reflects a $100 \%$ responses rate of the target respondents. Using a questionnaire that assesses the implementation of the on-the-job training program by the institution and partner agencies, results reveal that the on-the-job training program of the School of Accountancy, Business and Hospitality is effective and well-implemented for both institutional and company provisions from pre-orientation to post- on-the-job training activities. It further revealed that on-the-job training /Internships programs are able to train students to be more equipped and ready in their future careers and students manifested positive experience as exposures to real-life workplace environment and practices.
\end{abstract}

Keywords On-the-Job Training Program, Business Administration, Accountancy, Private HEI

\section{Introduction}

Education is considered as the bedrock to development as it contributes to the growth of every nation by improving the skills and productive capacity of workers. With this, Higher Education institutions (HEIs) in the Philippines continuously produce graduates in the different fields since they play a vital role in the development of knowledge-based economy (Dunning, 2002; Andrews \& Higson, 2008). However, it is also a challenge for HEIs in the Philippines not only to produce graduates, but more importantly to produce highly skilled graduates who can respond to the needs of the globalized world (Sleezer, et. al, 2004; Possa, 2006).

With globalization and the challenge of HEIs in producing graduates, employability then is becoming one of the goals in the education systems (Schulz, 2008) especially in developing countries such as the Philippines (Aguila, et. al., 2016; Ballon, 2007). Employability refers to the capability of graduates to obtain and maintain that is fulfilling (Hillage \& Pollard, 1998) and also effectively utilizing their knowledge, skills, and attitudes within a particular context to self-sufficiently realize their potential by sustaining their own employment (Boden \& Nedeva, 2010). Hence, it is very important that every graduate should see to it that adequate skills and competencies should be developed. However, a substantial number of studies had revealed that there is an increasing wide gap between the skills and capabilities of graduates and the requirements and demands of the work environment (King, 2003; Yunus \& Li, 2005; Wijesingha, 2010). And with this scenario, graduates' skills and competencies should be given an important consideration. Schultz (2008) stipulated that employability of graduates also involves skills in both the hard (academic and technical) and soft (personality traits and habits) skill areas.

In order to realize this goal, HEIs in the Philippines are coming up with mechanisms and initiatives to ensure that their graduates are really prepared to face the professional world. Among these mechanisms that are being employed by HEIs is the on-the-job training program. Since learning takes place in different avenues and forms, on-the-job training has been considered as a vital part of tertiary curriculum since this connects the gap between theory and practice as well as between classroom education and real 
industry life presenting a more precious learning experience among students (Laguador, 2013; Batool, Ellahi, \& Masood, 2012). A substantial number of studies stressed how important is on-the-job training among students before their college graduation. On-the-job trainings create an avenue for students to learn more about their profession and also generating values and substance in their skills (Edward Beck \& Halim, 2008; Ylagan, 2013). More importantly, on-the-job training for students serves as an instrument for increasing their employability after their graduation. On-the-job training has been used successfully in many countries to increase the integration of students into the labor market.

This study is anchored on the CHED Memorandum Order (CMO) No. 104 series of 2017 which is entitled the Revised Guidelines for Student Internship Program in the Philippines (SIPP) for All Programs issued by the Dr. Patricia Licuanan, the chair of Commission on Higher Education in the Philippines (Commission on Higher Education, 2017). This memorandum states that internship or on-the-job training program is meant to provide students with opportunity to complement their formal learning with practical knowledge, skills and desirable attitudes and to gain hands on experience in recognized Host Training Establishment (HTE). Specifically, the on-the-job training /Internship program has the following objectives:

1. Strengthen the implementation of the local internship through collaborative effort of the academe-industry linkage among HEIs and partner institution/establishment.

2. Establish the harmonious collaboration/linkages between higher education institutions (HEIs) and the Host Training Establishments (HTEs) for effective implementation of the program to support the educational environment of the student interns.

3. Train student interns under actual work place conditions.

For the scope of this memorandum, Article IV Section 7 states that CHED Memorandum Order (CMO) shall be applicable to all HEIs implementing Student Internship Program in the Philippines (SIPP) and students who have enrolled in the internship recognized/authorized higher education programs (Commission on Higher Education, 2017).

The memorandum further states that internship as part of the curriculum requirement broadens student interns' learning opportunities and acquisition of technical and life skills, practical knowledge, skills and competencies which shall serve as powerful motivator to strengthen the academe-industry linkage. With these, HEIs should come up with their creative academe-industry linkage plan appropriate to degree program requirement. Specifically, the on-the-job training /internship program has the following specific objectives intended for students:

1. Provide students with opportunities to apply relevant knowledge and skills acquired from forma education to actual work setting provided by reputable HTEs in the country.

2. Enhance the knowledge and skill acquired in formal education of student interns through employer-based training, in order for them to become more responsive to the future demands of the labor market.

3. Develop the life skills of the student interns, including those relevant to the values of professionalism and work appreciation. The student interns are expected to acquire soft skills necessary to address the demand of the employers such as communication skills, interpersonal skills, financial literacy, etc.

4. Acquire a professional work ethic in the course of internship.

The University of Saint Louis, with its aim of becoming a global university, adheres to its mission of preparing its students to become effective and competent missionary graduates across its programs such as the Business Administration and Accountancy (University of Saint Louis, n.d). With its current setting, on-the-job training programs in the Business Administration Program for both Financial Management and Marketing Management undergraduate courses are offered for one semester, to which, the students are to complete 300 hours. The students are employed in various financial and non-financial institutions in Tuguegarao City, the capital city in Northern Philippines. Meanwhile, the internship or on-the job training for Accountancy program is designed for 200 hours for one full semester. These students are deployed in various agencies either in Tuguegarao City or in Metro Manila.

Therefore, this study was conducted to assess the implementation of the on-the-job training programs of Business Administration and Accountancy Departments of the University of Saint Louis, one of the Higher Education Institutions in the Northern Philippines. By assessing the on-the-job training programs, the strengths and weaknesses of the programs are revealed in order for the University Administration to be more guided on how to further improve its implementation and ensure compliance on the standards set by the Commission on Higher Education. Other Higher Education Institutions in the country may find this study as a model to conduct the same in their own university/school setting and achieve the same purposes set forth in this study.

\section{Materials and Methods}

The study utilized descriptive method of research to evaluate the on-the-job training program of the Business Administration and Accountancy programs of University of Saint Louis, a Higher Education Institution in Northern Philippines. University of Saint Louis was chosen as this is one of the leading schools in the region that provides quality and excellent education in the field of Business Administration and Accountancy. A total of 142 students 
who had their on-the-job training in School Year 2018-2019 were the respondents of the study and this reflects a $100 \%$ response rate of the target respondents. Table 1 presents the profile of the undergraduate students. It can be gleaned in the table that majority of the respondents are under the program of specialization of Accountancy and most of them had their place of assignment among government financial institutions. A quantitative questionnaire was used and the items in the tool were based on the Commission on Higher Education Memorandum Order (CMO) No. 104 series of 2017 which is entitled as Revised Guidelines for Student Internship Program of the Philippines (SIPP). The questionnaire assesses the implementation of the on-the-job training program by the institution and partner agencies. The said tool consists of 19 items which is divided into three categories which are institutional evaluation (9 items), company evaluation (7 items), and effectiveness of the on-the-job training program ( 3 items) with the scale of 4=Strongly Agree; 3=Agree; 2=Disagree; $1=$ Strongly Disagree; $0=$ Not Applicable. Furthermore, the questionnaire, prior to its administration to target respondents was checked and validated by the members of the University Research and Development Center, Academic Deans, and the Vice President for Academics of University of Saint Louis. After which, the tool was personally administered by the researchers to the respondents. Furthermore, ethical considerations were employed by the researcher such as keeping the confidentiality and anonymity of the respondents, avoiding biases especially in the analysis of data and proper authorities and communication was ensured in the study.

Table 1. Profile of the Respondents

\begin{tabular}{|l|c|c|}
\hline Profile Variables & Frequency $(\mathrm{n}=142)$ & Percentage \\
\hline Program/Specialization & 60 & 53.10 \\
\hline Business Administration & 82 & 46.90 \\
\hline Accountancy & 59 & 39.82 \\
\hline Place of Assignment Financial & 31 & 16.81 \\
\hline $\begin{array}{l}\text { Government } \\
\text { Institutions }\end{array}$ & 17 & 15.04 \\
\hline $\begin{array}{l}\text { Government Non-Financial } \\
\text { Institutions }\end{array}$ & & \\
\hline Private Financial Institutions & & \\
\hline
\end{tabular}

Table 2. Scale and Qualitative Description in Evaluating On-the-Job Training Program

\begin{tabular}{|c|l|l|}
\hline \multirow{2}{*}{ Scale } & \multicolumn{2}{|c|}{ Qualitative Description } \\
\cline { 2 - 3 } & $\begin{array}{l}\text { Institutional/Company } \\
\text { Evaluation }\end{array}$ & Program Effectiveness \\
\hline $3.50-4.00$ & Fully Implemented (FI) & Very Effective (VE) \\
\hline $2.50-3.49$ & Implemented (I) & Effective (E) \\
\hline $1.50-2.49$ & Partially Implemented (PI) & Slightly Effective (SE) \\
\hline $1.00-1.49$ & Not Implemented (NI) & Not Effective (NE) \\
\hline
\end{tabular}

Finally, descriptive statistics such as frequency and percentage were used to describe the profile of the respondents and Mean was also used to evaluate the on-the-job training program. Table 2 presents the scale and qualitative description used in the evaluation.

\section{Results and Discussion}

Table 3 presents the assessment of the on-the-job training program of Business Administration students along institutional evaluation. As presented in the table, Business Administration (BA) students assess that the needed provisions for their on-the-job training are fully implemented. This implies that the Business Administration Department under the School of Accountancy, Business and Hospitality (SABH) ensures that students are provided with the necessary activities for a meaningful on-the-job training experience. Specifically, students emphasized that SABH through the BA Department conducted an orientation about the on-the-job training program, the requirements and preparations need and its expectations. This part of the on-the-job training programs plays a very crucial role in the success of the said program since this part will give on-the-job training students the knowledge and understanding not only about the program itself but also about other dimensions such as the workplace environment, work expectations and deliverables, ethical practices and behavior in the workplace, and other important matters. Orientation programs for on-the-job training are designed to help students make a successful transition to the work environment and to initiate the process of higher learning. These programs set the tone for student expectations and begin the process of integrating students into the work and professional culture. Successful orientation programming promotes confidence among on-the-job training students which may lead to a successful on-the-job training experience (Rothman, 2007).

Furthermore, the students also highlighted that BA Department provided the necessary assistance such as referrals or recommendations in finding the company for their on-the-job training and the department conducted an evaluation of their on-the-job training program upon completion. One of the best practices in the department is the Synthesis Program to which all students that have completed the on-the-job training are gathered in one hall to provide feedback through oral narrative report in front of panel members and their peers. It is true indeed that workplace feedback on performance on the job is a critical aspect of the learning process enabling on-the-job training students to recognize areas of strength and those needing improvement especially on their teaching methods and pedagogies (Coco, 2000). Also, recent studies had revealed that students' success in doing internship and on-the-job training programs can be seen if proper and regular feed backing had been conducted to monitor students' development and progress (Eyler \& Giles, 2014; Knouse \& Fontenot, 2008; Fagan, et. al., 2004). Furthermore, studies also show that feedback improves student's confidence, self-awareness and enthusiasm which will prepare them in the real-work setting (Kardash, 2000; Rothman, 2007). 
Table 3. Assessment of the On-the-Job Training Program of Business Administration Students along Institutional Evaluation

\begin{tabular}{|c|c|c|c|c|c|c|c|}
\hline \multirow{2}{*}{ Institutional Evaluation } & \multicolumn{5}{|c|}{$\%$ Responses } & \multirow{2}{*}{ Mean } & \multirow{2}{*}{ QD } \\
\hline & 4 & 3 & 2 & 1 & 0 & & \\
\hline $\begin{array}{l}\text { Conduct of an orientation about the on-the-job training program, the requirements and } \\
\text { preparations needed, and its expectations }\end{array}$ & 57 & 3 & 0 & 0 & 0 & 3.95 & FI \\
\hline $\begin{array}{l}\text { Provision of necessary assistance such as referrals or recommendations in finding the } \\
\text { company }\end{array}$ & 53 & 7 & 0 & 0 & 0 & 3.88 & FI \\
\hline Coordination with the company in the design and supervision of on-the-job training & 43 & 17 & 0 & 0 & 0 & 3.72 & FI \\
\hline Forging of Memorandum of Agreement (MOA) between USL and the company/agency & 43 & 11 & 3 & 2 & 1 & 3.55 & FI \\
\hline Academic preparations of Students to undertake company assignments and its challenges. & 37 & 21 & 2 & 0 & 0 & 3.58 & FI \\
\hline $\begin{array}{l}\text { Regular monitoring of the School/Department through the on-the-job training } \\
\text { Coordinator with regards to students' progress in the company }\end{array}$ & 37 & 20 & 3 & 0 & 0 & 3.57 & FI \\
\hline Giving of timely feedbacks to on-the-job training students & 44 & 16 & 0 & 0 & 0 & 3.73 & FI \\
\hline $\begin{array}{l}\text { Conduct of an on-the-job training program evaluation upon completion of students in their } \\
\text { on-the-job training }\end{array}$ & 53 & 7 & 0 & 0 & 0 & 3.88 & FI \\
\hline Giving of results of company assessment to on-the-job training students & 46 & 13 & 1 & 0 & 0 & 3.75 & FI \\
\hline Total/Category Mean & 45 & 12 & 1 & 1 & 1 & 3.74 & FI \\
\hline
\end{tabular}

Table 4. Assessment of the On-the-Job Training Program of Accountancy Students along Institutional Evaluation

\begin{tabular}{|c|c|c|c|c|c|c|c|}
\hline \multirow{2}{*}{ Institutional Evaluation } & \multicolumn{5}{|c|}{ \% Responses } & \multirow{2}{*}{ Mean } & \multirow{2}{*}{ QD } \\
\hline & 4 & 3 & 2 & 1 & 0 & & \\
\hline $\begin{array}{l}\text { Conduct of an orientation about the on-the-job training program, the requirements and } \\
\text { preparations needed, and its expectations }\end{array}$ & 72 & 10 & 0 & 0 & 0 & 3.88 & FI \\
\hline $\begin{array}{l}\text { Provision of necessary assistance such as referrals or recommendations in finding the } \\
\text { company }\end{array}$ & 55 & 20 & 5 & 2 & 0 & 3.56 & FI \\
\hline Coordination with the company in the design and supervision of on-the-job training & 60 & 22 & 0 & 0 & 0 & 3.73 & FI \\
\hline Forging of Memorandum of Agreement (MOA) between USL and the company/agency & 55 & 8 & 1 & 9 & 9 & 3.11 & I \\
\hline Academic preparations of Students to undertake company assignments and its challenges. & 47 & 29 & 6 & 0 & 0 & 3.50 & FI \\
\hline $\begin{array}{l}\text { Regular monitoring of the School/Department through the on-the-job training } \\
\text { Coordinator with regards to students' progress in the company }\end{array}$ & 60 & 22 & 0 & 0 & 0 & 3.73 & FI \\
\hline Giving of timely feedbacks to on-the-job training students & 59 & 23 & 0 & 0 & 0 & 3.72 & FI \\
\hline $\begin{array}{l}\text { Conduct of an on-the-job training program evaluation upon completion of students in their } \\
\text { on-the-job training }\end{array}$ & 64 & 13 & 2 & 0 & 3 & 3.65 & FI \\
\hline Giving of results of company assessment to on-the-job training students & 55 & 21 & 2 & 0 & 4 & 3.50 & FI \\
\hline Total/Category Mean & 58 & 18 & 2 & 2 & 2 & 3.60 & FI \\
\hline
\end{tabular}

Similar to Table 3, Table 4 reveals that the provisions in the on-the-job training program or Internship of the Accountancy Program are fully implemented by the University. The Accountancy students assessed that SABH, through its Accountancy Program, conducts orientation about the on-the-job training program and conducts evaluation of Internship/ on-the-job training program upon completion. It is practiced in the department that before students are set forth in their different agencies for the on-the-job training, the university through the Academic and Program Chairs really sees to it that students are well briefed and properly oriented about their respective workplaces and the school's expectations are properly instilled.

Meanwhile, the provision of necessary assistance such as referrals or recommendations in finding the company is rated by the students as fully implemented. The Accountancy Program had already engaged to different agencies in the City and even in Metro Manila for the internship of Accountancy students. The department is the one in charge in looking for companies to which the students are to be deployed. The choice of companies is aligned with the job expectations of the trainees. For this reason that industries and partner agencies may collaborate with the academe on what skills and programs the school and department may introduce and implement to further enhance the hard skills of on-the-job training students (An \& Mauhay, 2016; Patacsil \& Tablatin, 2017). Furthermore, the forging of Memorandum of Agreement (MOA) between USL and the company/agency is rated by the students as implemented. 
Table 5. Assessment of the On-the-Job Training Program of Business Administration Students along Company Evaluation

\begin{tabular}{|c|c|c|c|c|c|c|c|}
\hline \multirow{2}{*}{ Company Evaluation } & \multicolumn{5}{|c|}{$\%$ Responses } & \multirow{2}{*}{ Mean } & \multirow{2}{*}{ QD } \\
\hline & 4 & 3 & 2 & 1 & 0 & & \\
\hline Appropriateness of the type of training required and or/desired & 45 & 15 & 0 & 0 & 0 & 3.75 & FI \\
\hline Designed of the training to meet the course objectives and expectations. & 48 & 12 & 0 & 0 & 0 & 3.80 & FI \\
\hline $\begin{array}{l}\text { Coordination with USL, through the on-the-job training Coordinator, in the design and } \\
\text { supervision of the on-the-job training }\end{array}$ & 41 & 19 & 0 & 0 & 0 & 3.68 & FI \\
\hline Company Treatment to on-the-job training students & 46 & 14 & 0 & 0 & 0 & 3.77 & FI \\
\hline $\begin{array}{l}\text { Facilitation of the training, including the provision of the necessary resources/facilities } \\
\text { needed to achieve the objectives of the on-the-job training program }\end{array}$ & 46 & 14 & 0 & 0 & 0 & 3.77 & FI \\
\hline Assigned a supervisor to oversee on-the-job training students' work & 46 & 14 & 0 & 0 & 0 & 3.77 & FI \\
\hline Supervision of the Supervisor through regular meeting, consultation or advise & 40 & 19 & 1 & 0 & 0 & 3.65 & FI \\
\hline Total/Category Mean & 44 & 15 & 1 & 0 & 0 & 3.74 & FI \\
\hline
\end{tabular}

Furthermore, Table 5 above shows the assessment of Business Administration students of their on-the-job training program along company evaluation. It is notable that students rated the design of their on-the-job training have met the course objectives and expectations as fully implemented. The BA department ensures that the company to which the students are deployed for training is able to meet what is required of the course which means that the nature and environment of the workplace is conducive and is really training ground for future BA graduates. Internships should enable interns to learn career-related skills in a work-place setting and in learning about the reality of professional practice; the interns will also have acquired skills relevant to the success of their future careers (Beck \& Halim, 2008).

Also, the students assessed the treatment of the company to the trainees, the facilitation of the training, including the provision of the necessary resources/facilities needed to achieve the objectives of the on-the-job training program and the assignment of a supervisor to oversee the trainees work as fully implemented. Internship can assist students to bridge the gap between the academic learning process and the practical reality (Lam \& Ching, 2007). McMahon and Quinn (1995) note that internship is considered as 'supervised work experiences' where students are closely supervised during their internship attachment. In the current study, students rated that the supervision of the supervisor through regular meeting, consultation or advice is fully implemented.

In Table 6, it shows the assessment of Accountancy students of the on-the-job training program along company evaluation. It can also be shown from the table that provisions with regard to responsibilities and duties of companies and partner agencies of USL are fully implemented. This only implies that the government and private financial and non-financial institutions are good training platforms for the training the future professionals. There is no doubt that internships are useful experiences for students and can result in lucrative jobs and students connecting and applying their academic experiences to internships may increase their opportunities for employment or entrepreneurship (Nicholas, 2016). Allowing the graduating students to apply what they have learned from books in a work environment through on-the-job training would develop their work values and attitude necessary to achieve the ultimate goal of producing efficient and effective leaders and professionals in cross-cultural and multidisciplinary undertakings (An \& Mauhay, 2016; Busby \& Gibson, 2010).

Furthermore, the results also imply that industry partners are true to their responsibility in providing the students with opportunities to work with the specific department where they can best apply the theories, principles and ideas learned in the academe. It is also important to note that supervisors are employed for the duration of the on-the-job training program in order to ensure effective learning to on-the-job training students. Along with this program are trainings that are provided by some companies from different industries in which the trainee gains knowledge contributory to the organization. Through their supervision and support, trainees will nurture the knowledge that can build up their potentials on being professionals. Work values are also generated to the students through the experience given by this program that will really help them as they enter the professional world.

Table 7 presents the effectiveness of the on-the-job training program to Business Administration students. It can be gleaned that students rated all the provisions listed in the table to be very effective. This implies that the on-the-job training experience of the students is very realistic in realizing their future career. The rationale in offering the internship attachment as part of the academic programme is that students benefit from these internship experiences and exposure. Benefits include improvements in career-related direction (Lubbers, 2001), gaining practical experience (Lubbers, 2001 as cited by Bukaliya, 2012), leadership (Cook et al., 2004) and understanding of the business applications of classroom learning (Cook et al., 2004). Workplace experiences afford students exposure to future workplaces and opportunities to explore how they are positioned in terms of graduate knowledge, skills, and proficiencies (Billett, 2001). 
Table 6. Assessment of the On-the-Job Training Program of Accountancy Students along Company Evaluation

\begin{tabular}{|c|c|c|c|c|c|c|c|}
\hline \multirow{2}{*}{ Company Evaluation } & \multicolumn{5}{|c|}{ \% Responses } & \multirow{2}{*}{ Mean } & \multirow{2}{*}{ QD } \\
\hline & 4 & 3 & 2 & 1 & 0 & & \\
\hline Appropriateness of the type of training required and or/desired & 37 & 36 & 5 & 4 & 0 & 3.29 & I \\
\hline Designed of the training to meet the course objectives and expectations. & 43 & 28 & 10 & 1 & 0 & 3.38 & I \\
\hline $\begin{array}{l}\text { Coordination with USL, through the on-the-job training Coordinator, in the design and } \\
\text { supervision of the on-the-job training }\end{array}$ & 59 & 22 & 1 & 0 & 0 & 3.71 & FI \\
\hline Company Treatment to on-the-job training students & 77 & 5 & 0 & 0 & 0 & 3.94 & FI \\
\hline $\begin{array}{l}\text { Facilitation of the training, including the provision of the necessary resources/facilities } \\
\text { needed to achieve the objectives of the on-the-job training program }\end{array}$ & 58 & 23 & 0 & 1 & 0 & 3.68 & FI \\
\hline Assigned a supervisor to oversee on-the-job training students' work & 70 & 11 & 1 & 0 & 0 & 3.84 & FI \\
\hline Supervision of the Supervisor through regular meeting, consultation or advise & 60 & 19 & 3 & 0 & 0 & 3.70 & FI \\
\hline Total/Category Mean & 58 & 20 & 3 & 1 & 0 & 3.65 & FI \\
\hline
\end{tabular}

Table 7. Effectiveness of the On-the-Job Training Program of Business Administration Students

\begin{tabular}{|c|c|c|c|c|c|c|c|}
\hline \multirow{2}{*}{ Program Effectiveness } & \multicolumn{5}{|c|}{$\%$ Responses } & \multirow{2}{*}{ Mean } & \multirow{2}{*}{ QD } \\
\hline & 4 & 3 & 2 & 1 & 0 & & \\
\hline Exposure to real world problems and practice & 41 & 18 & 1 & 0 & 0 & 3.67 & $\mathrm{VE}$ \\
\hline Development of self-confidence, self-motivation, and positive attitude towards work. & 50 & 9 & 1 & 0 & 0 & 3.82 & $\mathrm{VE}$ \\
\hline Improvement of personal skills and human relations. & 50 & 10 & 0 & 0 & 0 & 3.83 & $\mathrm{VE}$ \\
\hline Total/Category Mean & 47 & 12 & 1 & 0 & 0 & 3.77 & VE \\
\hline
\end{tabular}

Table 8. Effectiveness of the On-the-Job Training Program of Accountancy Students

\begin{tabular}{|l|c|c|c|c|c|c|c|}
\hline \multicolumn{1}{|c|}{ Program Effectiveness } & \multicolumn{4}{|c|}{ \% Responses } & \multirow{2}{*}{ Mean } & \multirow{2}{*}{ QD } \\
\cline { 2 - 6 } & 4 & 3 & 2 & 1 & 0 & \\
\hline Exposure to real world problems and practice & 52 & 24 & 6 & 0 & 0 & 3.65 & VE \\
\hline Development of self-confidence, self-motivation, and positive attitude towards work. & 60 & 21 & 1 & 0 & 0 & 3.56 & VE \\
\hline Improvement of personal skills and human relations. & 65 & 17 & 0 & 0 & 0 & 3.79 & VE \\
\hline Total/Category Mean & 59 & 21 & 2 & 0 & 0 & 3.69 & VE \\
\hline
\end{tabular}

Lastly, table 8 shows the assessment of Accountancy students on the effectiveness of the on-the-job training program. The results reveal that accountancy students believe that the on-the-job training program is also very effective in realizing their future career. Also, the students assessed that their on-the-job training experience is very effective in developing them holistically. With the on-the-job training program, students were able to apply the knowledge, demonstrate necessary skills, enhance the attitude and hone the character of the students towards a holistic appreciation of the actual workplace (De Chavez, et. al., 2016). The internship experience is argued to be beneficial in socializing the student through training, teamwork assignments, meetings with clients or employees, and various events hosted by the organization they are attached to during their internship (Lubbers, 2007/8 as cited by Bukaliya, 2012). Mihail (2006) noted that interns have successfully developed their personal skills, particularly relating to information technology, time management, communication skills, teamwork, specialist knowledge and ability to prioritize tasks.

\section{Conclusions}

The study concludes that the on-the-job training programs for Business Administration and Accountancy departments under the School of Accountancy, Business and Hospitality of the University of Saint Louis is effective along institutional and company evaluations. It also concludes that the institution implements the on-the-job training programs effectively, from pre-orientation to poston-the-job training activities and the companies to which the students had their on-the-job trainings are assessed to be effective in training the students. Furthermore, the on-the-job training /internships programs of the School of Accountancy, Business and Hospitality are able to train students to be more equipped and ready in their future careers as students manifested positive experience as exposures to real-life workplace environment and practices.

\section{Recommendations}

The School of Accountancy, Business and Hospitality 
through its Business Administration and Accountancy Departments should maintain its pre-orientation and poston-the-job training activities in order for the students to be familiarized with their assigned companies/institutions and for the University to properly monitor the students.

The duration of the on-the-job training for the Accountancy program should be increased from 200 hours to 300 hours. Also, the semester to which the on-the-job training is offered should be in the last semester in the student's last year in college. Further, the School of Accountancy, Business and Hospitality should forge more linkage and identify more partner agencies to cater the increasing number of future trainees in the Business Administration and Accountancy Departments.

The study is limited in evaluating two departments in the university and with this; it is further recommended that same study be conducted to evaluate the on-the-job training programs of its other departments.

For other Higher Education Institutions in the Philippines, the tool used in this study may be adopted in order for them to evaluate their respective on-the-job training programs since items in the tool are based on the guidelines of the Commission of Higher Education, to which every Higher Education Institution should abide into.

\section{REFERENCES}

[1] Aguila, G. M., De Castro, E. L., Dotong, C. I., \& Laguador, J. M. (2016). Employability of computer engineering graduates from 2013 to 2015 in one private higher education institution in the Philippines. Asia Pacific Journal of Education, Arts and Sciences, 3(3), 48-54.

[2] An, I. L., \& Mauhay, R. C. A. (2016). Interns' Feedback on Industry Partners: Inputs for an Enhanced Internship Program. Asia Pacific Journal of Education, Arts and Sciences, 3(2).

[3] Andrews, J., \& Higson, H. (2008). Graduate employability, 'soft skills' versus 'hard' business knowledge: A European study. Higher education in Europe, 33(4), 411-422.

[4] Ballon, A. E. (2007). Predictors of Employability of the Graduates of Technological Institute of the Philippines Quezon City. TIP Research Journal Quezon City, 4(1), 1-1.

[5] Batool, Z., Ellahi, N., \& Masood, A. (2012). National internship programme and its evaluation: A case study of Punjab region. Academic Research International, 2(2), 562.

[6] Boden, R., \& Nedeva, M. (2010). Employing discourse: universities and graduate 'employability'. Journal of Education Policy, 25(1), 37-54.

[7] Bukaliya, R. (2012). The potential benefits and challenges of internship programmes in an ODL institution: A case for the Zimbabwe Open University. International journal on new trends in education and their implications, 3(1), 118-133.

[8] Coco, M. (2000). Internships: A try before you buy arrangement. SAM Advanced Management Journal, 65(2), 41

[9] Cook, Sherry J., Stephen R. Parker, \& Charles E. Pettijohn (2004). The perceptions of interns: A longitudinal case study. Journal of Education for Business, 79, 179-185

[10] Commission on Higher Education. (2017). CHED Memorandum Order. Retrieved fromhttps://ched.gov.ph/w p-content/uploads/2018/03/CMO-NO.-104-S.-2017.pdf

[11] Dunning, J. H. (2002). Regions, globalization, and the knowledge-based economy. Oxford university press.

[12] Edward Beck, J., \& Halim, H. (2008). Undergraduate internships in accounting: What and how do Singapore interns learn from experience?. Accounting Education: an international journal, 17(2), 151-172.

[13] Eyler, J., \& Giles Jr, D. (2014). The importance of program quality in service-learning. In Service-learning (pp. 75-94). Routledge.

[14] Fagan, T. J., Ax, R. K., Resnick, R. J., Liss, M., Johnson, R. T., \& Forbes, M. R. (2004). Attitudes Among Interns and Directors of Training: Who Wants to Prescribe, Who Doesn't, and Why. Professional Psychology: Research and Practice, 35(4), 345.

[15] Gloria, A. M., Hird, J. S., \& Tao, K. W. (2008). Self-reported multicultural supervision competence of White predoctoral intern supervisors. Training and Education in Professional Psychology, 2(3), 129.

[16] Hillage, J., \& Pollard, E. (1998). Employability: developing a framework for policy analysis.

[17] Jacobs, R. L., \& Jaseem Bu-Rahmah, M. (2012). Developing employee expertise through structured on-the-job training (S-OJT): an introduction to this training approach and the KNPC experience. Industrial and Commercial Training, 44(2), 75-84.

[18] Kardash, C. M. (2000). Evaluation of undergraduate research experience: Perceptions of undergraduate interns and their faculty mentors. Journal of educational psychology, 92(1), 191.

[19] King, Z. (2003). New or traditional careers? A study of UK graduates' preferences. Human resource management journal, 13(1), 5-26.

[20] Knouse, S. B., \& Fontenot, G. (2008). Benefits of the business college internship: A research review. Journal of Employment Counseling, 45(2), 61-66.

[21] Lam, T., Ching, L. (2006). An exploratory study of an internship program: The case of Hong Kong students. Hospitality Management, 26, 336-351.

[22] Laguador, J. M. (2013). Developing students' attitude leading towards a life-changing career. Educational Research International, 1(3), 28-33.

[23] McMahon, U., \& Quinn, U. (1995). Maximizing the hospitality management student work placement experience: A case study. Education and Training, 37, 13-17.

[24] Mihail, D.M., (2006). Internship at Greek Universities: An exploratory study. Journal of Workplace Learning, 18, 28-41. 
[25] Newman, A., Rose, P. S., \& Teo, S. T. (2016). The role of participative leadership and trust - based mechanisms in eliciting intern performance: Evidence from China. Human Resource Management, 55(1), 53-67.

[26] Nicholas, A. J. (2016). Internships: Experiential learning, academic connection and assessment.

[27] Patacsil, F. F., \& Tablatin, C. L. S. (2017). Exploring the importance of soft and hard skills as perceived by IT internship students and industry: A gap analysis. Journal of Technology and Science Education, 7(3), 347-368.

[28] Possa, G. (2006). Europe's universities in response to Europe's challenges. Higher education in Europe, 31(4), 355-357.

[29] Rothman, M. (2007). Lessons learned: Advice to employers from interns. Journal of Education for business, 82(3), $140-144$.

[30] Schulz, B. (2008). The importance of soft skills: Education beyond academic knowledge

[31] Shoho, A. R., Barnett, B. G., \& Martinez, P. (2012). Enhancing" OJT" Internships with Interactive Coaching. Planning and Changing, 43, 161-182.

[32] Sleezer, C. M., Conti, G. J., \& Nolan, R. E. (2004). Comparing $\mathrm{CPE}$ and HRD programs: Definitions, theoretical foundations, outcomes, and measures of quality. Advances in developing human resources, 6(1), 20-34.

[33] Wijesingha, R. (2010). Towards productive higher education Daily News (Speech on the Adjournment Motion on University, May 20 Parliament) Reforms.

[34] University of Saint Louis. (n.d). Vision-Mission of University of Saint Louis. Retrieved fromhttp://usl.edu.ph/ about-usl/vision-mission/

[35] Ylagan, A. P. (2013). Intensifying the OJT Program of the College of Business Administration, Lyceum of the Philippines University-Batangas. E-International Scientific Research Journal, 5(1), 220-220.

[36] Yunus, K., \& Li, S. (2005). Matching job skills with needs. Business Times, 1 . 